\title{
Profile of people with stomas from a municipal health service in Southern of Brazil
}

Perfil de pessoas com estomias de um serviço de saúde municipal no Sul do Brasil Perfil de personas con ostomías de un servicio de salud municipal en el Sur de Brasil Mariéle Rodrigues Barbosa ${ }^{1}$, Bruna Sodré Simon ${ }^{1}$, Cenir Gonçalves Tier ${ }^{1}$, Raquel Potter Garcia ${ }^{1}$, Débora Schlotefeldt Siniak', Sandra Ost Rodrigues ${ }^{2}$

ORCID IDs

Barbosa MR (iD https://orcid.org/0000-0001-7858-9394

Simon BS (D) https://orcid.org/0000-0003-3855-1310

Tier CG (D) https://orcid.org/0000-0003-1539-7816

Garcia RP (D) https://orcid.org/0000-0002-5503-7981

Siniak DS (iD https://orcid.org/0000-0002-7689-6953

Rodrigues SO (D) https://orcid.org/0000-0002-1715-9881

\section{HOW TO CITE}

Barbosa MR; Simon BS; Tier CG; Garcia RP; Siniak DS; Rodrigues SO. Profile of people with stomas from a municipal health service in Southern of Brazil. ESTIMA, Braz. J. Enterostomal Ther., 16:e1318. doi: 10.30886/estima.v16.465

Article extracted from the Course Conclusion Paper entitled "Profile of people with stomas of a municipality in the western border of Rio Grande do Sul" presented in 2016 to the Graduation Nursing Course of the Universidade Federal do Pampa, Uruguaiana/RS, Brazil.

\begin{abstract}
Objective: To characterize the sociodemographic and clinical profile of the population with stoma that resides in the city of Uruguaiana (Rio Grande do Sul, Brazil). Method: A quantitative, documental, retrospective and exploratory study realized in May 2016. It were analyzed 34 forms of people with stomas; descriptive and percentage statistics were applied. Results: Men predominance (55.9\%) and a higher incidence in the 61-70 age group (32.3\%) were identified. The neoplasias are the main cause for the manufacture of stomas (61.7\%), all of which are intestinal (100\%). Conclusion: It is believed that this research may contribute to the planning of adequate and specialized assistance for these people. The identification of the Family Health Strategy to which each user belongs will assist in the planning of future actions in order to provide care that offers guidance and support.
\end{abstract}

DESCRIPTORS: Stoma; Stomatherapy; Nursing; Health profile.

1 Universidade Federal do Pampa - Curso de Graduação em Enfermagem - Uruguaiana/RS - Brazil.

2Universidade Regional Integrada do Alto Uruguai e das Missões - Curso de Graduação em Enfermagem - Santiago/RS - Brazil.

Corresponding author: Bruna Sodré Simon | BR 472, Km 585, Caixa Postal 118 | ZIP Code: $97501-970$ - Uruguaiana/RS - Brazil | E-mail: enf.brusimon@gmail.com

Received: Mar. 04, 2017 | Accepted: Feb. 14, 2018 


\section{RESUMO}

Objetivo: Caracterizar o perfil sociodemográfico e clínico da população com estomia que reside no município de Uruguaiana (Rio Grande do Sul, Brasil). Método: Estudo quantitativo, documental, retrospectivo e exploratório realizado em maio de 2016. Analisaram-se 34 fichas cadastrais de pessoas com estomias; aplicou-se estatística descritiva e percentual. Resultados: Identificaram-se o predomínio do sexo masculino (55,9\%) e uma maior incidência na faixa etária de 61 a 70 anos (32,3\%). As neoplasias são a principal causa para a confecção das estomias (61,7\%), sendo todas intestinais (100\%). Conclusão: Acredita-se que esta pesquisa poderá contribuir para o planejamento de uma assistência adequada e especializada destinada a essas pessoas. A identificação da Estratégia Saúde da Família a que pertence cada usuário auxiliará no planejamento de ações futuras, a fim de prestar um cuidado que oferte orientações e apoio.

DESCRITORES: Estomia; Estomaterapia; Enfermagem; Perfil de saúde.

\section{RESUMEN}

Objetivo: Caracterizar el perfil sociodemográfico y clínico de la población con ostomía que vive en el municipio de Uruguaiana (Rio Grande do Sul, Brasil). Método: Estudio cuantitativo, documental, retrospectivo y exploratorio realizado en mayo de 2016 . Se analizaron 34 fichas de registro de personas con ostomías; se aplicó estadística descriptiva y porcentual. Resultados: Se identificaron el predominio del sexo masculino (55,9\%) y una mayor incidencia en la franja etaria de 61 a 70 años (32,3\%). Las neoplasias son la principal causa para la confección de las ostomías (61,7\%), siendo todas intestinales (100\%). Conclusión: Se cree que esta investigación podrá contribuir para la planificación de una asistencia adecuada y especializada destinada a estas personas. La identificación de la Estrategia Salud de la Familia a que pertenece cada usuario ayudará en la planificación de acciones futuras, a fin de prestar un cuidado que ofrezca orientaciones y apoyo.

DESCRIPTORES: Ostomía; Estomaterapia; Enfermería; Perfil de salud.

\section{INTRODUCTION}

People of all ages, ethnic groups, cultures and socioeconomic levels have been affected by chronic conditions. These have slow evolution, usually have numerous causes and vary according to time, lifestyle, heredity and exposure to environmental and physiological factors. It is known that among the chronic conditions, cancer, although it represents the second place in mortality rates, is on the rise, being behind only the pathologies that affect the cardiovascular system ${ }^{1}$.

In Brazil, among the most recurrent chronic conditions, are neoplasias. Colon and rectum cancer is one of the most frequent types of morbidity and mortality, occupying the third place among women and the fourth among men². As a result, many people go through the process of making a stoma, which has as its main cause the neoplasias, and may also have as etiology inflammatory and congenital diseases and traumatisms ${ }^{3}$.

The elimination stoma consists of the artificial opening of the abdominal wall to the outside, surgically created and may be temporary or permanent, in which is externally coupled in the abdomen a bag for collection of faeces and/or urine $e^{4}$

The person with a stoma requires a lot of specific care, as well as having a compromised body image, has psychological and social changes, requiring follow-up by a multidisciplinary team ${ }^{5}$. It can be seen that a multidisciplinary service can act directly in the promotion of health, in the prevention of complications and in the assistance in selfesteem, besides promoting the professional-patient-health services relationship ${ }^{5}$.

In this sense, it is necessary to draw up a continuous and individualized nursing care plan, so that these people return to their activities of daily living, considering that these professionals participate actively in all stages of care ${ }^{6}$.

Through these care, the nursing team can assist in the rehabilitation of these people, being present many times from the moment of diagnosis, going through the hospitalization period and continuing in the postoperative and rehabilitative follow-up. As a health educator, the nurse needs to guide the patient and its relatives in the care of the stomas that should be performed at home, such as hygiene, exchange of the bag collector, food and self-care ${ }^{8}$. Nursing orientations through health education become more relevant in the care of the person with the stoma, because through this process the autonomy can reach, the understanding of the etiological process and also the treatment ${ }^{8}$.

This study is relevant due to the necessity to provide data, in order to develop assistance strategies and to realize a better planning of nursing care for this population, and intends to 
boost the elaboration of projects that attend these people. In front of these considerations, it is necessary for nursing professionals to know the profile of this clientele, in order to better plan clinical care, and that health managers also have this knowledge for the implementation of public health policies.

For this purpose, it was questioned: profile knowledge of people with stomas attended by the Municipal Health Department of Uruguaiana, Rio Grande do Sul (Brazil), will contribute to the implementation of future actions as a way to help promote an improvement quality of life? Thus, the objective of this study was to characterize the sociodemographic and clinical profile of the population with a stoma that resides in the city of Uruguaiana, RS.

\section{METHOD}

This is a quantitative, documental, retrospective and exploratory study developed in May 2016, in the city of Uruguaiana, RS. The data were collected from 34 forms of people with registered stomas in the service of distribution of bags collector and other devices of the Municipal Health Department that consist the system of Management of Users with Disabilities (MUD). Included were the records of people who had intestinal and/or urinary, permanent or temporary stomas; and one participant was excluded because it did not reside in the study municipality.

The data were collected from the printed document named Patient Register, from the MUD archive. These were obtained through the filling of a data collection instrument with items on personal identification, socioeconomic aspects and types and etiology of the stomas. The variables studied were: gender, age and diagnosis according to the International Classification of Diseases (ICD-10). The data were organized in a spreadsheet in the $\operatorname{Excel}{ }^{\circledR}$ program and analyzed through descriptive and percentage statistics.

Ethical principles were followed according to Resolution No. 466/12 of the National Research Council, regulating research with human beings, preserving the anonymity of all participants'. The research followed the procedures of institutional authorizations and was sent to the Ethics Committee of the Federal University of Pampa, receiving approval opinion No. 1.462.372.

\section{RESULTS}

The sample consisted of 34 forms, which correspond to all people registered until the date of data collection in the MUD of the municipality. Regarding gender and age, the data are described in Table 1.

In the intercrossing of the variables age range and gender, considering the information available in the records of the MUD, it was observed that the age with the highest incidence is 61 to 70 years, being $31.5 \%(\mathrm{n}=6)$ men and $33.3 \%(n=5)$ of women, totaling $32.35 \%(n=11)$.

Table 1. Sedimentation of people $(n=34)$ with stomas according to age group and gender. Uruguaiana, Rio Grande do Sul, Brazil, 2016.

\begin{tabular}{|c|c|c|c|c|c|c|}
\hline \multirow{2}{*}{$\begin{array}{l}\text { Age } \\
\text { range } \\
\text { (years) }\end{array}$} & \multicolumn{2}{|c|}{ Male } & \multicolumn{2}{|c|}{ Female } & \multicolumn{2}{|c|}{ Total } \\
\hline & $\mathrm{n}$ & $\%$ & $\mathrm{n}$ & $\%$ & $\mathrm{n}$ & $\%$ \\
\hline $0-10$ & - & - & 1 & 6.7 & 1 & 3.0 \\
\hline $11-20$ & 3 & 15.8 & - & & 3 & 8.8 \\
\hline $21-30$ & - & - & - & 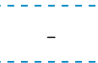 & - & - \\
\hline $31-40$ & 5 & 26.3 & - & - & 5 & 14.7 \\
\hline $41-50$ & - & - & 2 & 13.3 & 2 & 5.9 \\
\hline $51-60$ & 3 & 15.8 & 4 & 26.7 & 7 & 20.6 \\
\hline $61-70$ & 6 & 31.5 & 5 & 33.3 & 11 & 32.3 \\
\hline $71-80$ & 1 & 5.3 & 2 & 13.3 & 3 & 8.8 \\
\hline $81-90$ & 1 & 5.3 & 1 & 6.7 & 2 & 5.9 \\
\hline Total & 19 & 100 & 15 & 100 & 34 & 100 \\
\hline
\end{tabular}

Source: Research data, Uruguaiana/RS, 2016.

The municipality scenario of study is divided into 18 units of Family Health Strategy (FHS) that comprise the rural and urban regions. Thus, regarding the origin, it was identified that in 12 of these FHS, there is a person with a stoma belonging to the area, and a FHS has $26.4 \%$ $(n=09)$ of the respondents, that is, a quantitative relevant to the area. However, it should be emphasized that this FHS is the one with the largest area of coverage in the municipality.

As for the etiology of the stomas, $61.7 \%(n=21)$ are the main malignant neoplasms, and it was verified that of the 34 people registered, the diagnosis with the highest 
incidence was ICD-C20; this and the other etiologies are described in Table 2.

Table 2. Classification of stomas $(n=34)$ regarding the etiology. Uruguaiana, Rio Grande do Sul, Brazil, 2016.

\begin{tabular}{|c|c|c|}
\hline Etiology & $\mathrm{n}$ & $\%$ \\
\hline Malignant neoplasia of rectum & 12 & 35.2 \\
\hline Fecal incontinence & 5 & 14.6 \\
\hline Malignant neoplasia of colon & 3 & 8.7 \\
\hline Malignant neoplasia of sigmoid colon & 3 & 8.7 \\
\hline $\begin{array}{l}\text { Diverticular disease of the large } \\
\text { intestine with perforation and abscess }\end{array}$ & 2 & 5.8 \\
\hline Rectum trauma & 1 & 3.0 \\
\hline $\begin{array}{l}\text { Malignant neoplasia of ascending } \\
\text { colon }\end{array}$ & 1 & 3.0 \\
\hline Spleen trauma & 1 & 3.0 \\
\hline $\begin{array}{l}\text { Secondary malignant neoplasia of } \\
\text { other digestive organs, unspecified }\end{array}$ & 1 & 3.0 \\
\hline Volvo with handle & 1 & 3.0 \\
\hline Intestinal fistula & 1 & 3.0 \\
\hline Malignant neoplasia of cecum & 1 & 3.0 \\
\hline Crohn's disease of the large intestine & 1 & 3.0 \\
\hline Crohn's disease of the small intestine & 1 & 3.0 \\
\hline Total & 34 & 100 \\
\hline
\end{tabular}

Source: Research data, Uruguaiana/RS, 2016.

\section{DISCUSSION}

In Brazil, it is quite complex to approach the epidemiology of people with stomas, since systematized records of information are needed. Territorial extent, deficit and, in some cases, lack of records, together with communication difficulties, are some factors involved in the precarious systematization of data and health knowledge ${ }^{10}$.

In this study, men predominated, and this result was also verified in the population of Minas Gerais ${ }^{10}$, in Piaui ${ }^{11}$, in the south of Santa Catarina ${ }^{12}$ and in Distrito Federal ${ }^{3}$, but this diverges from another study also realized in Rio Grande do Sul ${ }^{13}$.

In the southern region of Brazil, colon and rectum cancer in men is the fourth most frequent. It is worth noting that several factors are related to these causes, such as genetics, inflammatory diseases of the colon and inadequate life habits, such as food, alcohol and sedentarism ${ }^{15}$. It can be seen that colorectal cancer is a pathology that can be characterized as a public health problem not only in Brazil, but also in other countries, like Chile, where of 322 patients who were submitted intestinal surgery, 69\% presented colon tumor and $31 \%$ of rectum ${ }^{15}$.

In the studied group, it can be observed the predominance of patients with stomas aged between 61 and 70 years, 32.3\% $(\mathrm{n}=11)$. This data is in agreement with other studies ${ }^{3,10,11,13}$, which identified that the average prevailing age of people with stomas was classified in the same way.

The incidence in people over 60 years can be explained in the sense that this age group has been exposed to carcinogenic agents for a longer time. However, due to diagnostic difficulties, colorectal cancer, which is one of the main etiologies of the intestinal stomas, is often diagnosed late, which is related to the index of elderly people with colostomies $^{16}$.

This fact may also be related to the increase in life expectancy worldwide and, consequently, to an increase in chronic conditions. In addition, the results regarding the distribution of the population by age group reflect the aging population, considering that the majority of the people registered in the MUD is over 60 years.

These results reflect the demographic census of $2010^{17}$, in which the Brazilian population totaled 190.755.199 people. The number of elderly people, over 60 years old, was 20.590 .599 people, or approximately $10.8 \%$ of the total population. For the year 2020, it is estimated that the number of people over 60 years reaches 25 million, totaling $11.4 \%$ of the Brazilian population ${ }^{18}$.

It was decided to map the location of the domicile of people with stomas in the studied municipality, considering their territorial extension. Thus, knowing the health unit of the family to which these people belong allows healthcare professionals to assist in the rehabilitation, adaptation and quality of life of all involved, since, often, the person at the time of hospital discharge receives referral for the service of distribution of the bags, but the health unit to which it belongs takes time to realize this survey.

In this sense, a study realized in RS reports that when the family health team knows its territory and scope, it is possible to trim the edges and fill the gaps of unattended places $^{19}$.

Regarding the etiology, the neoplasias had a higher incidence in the manufacture of the stoma, resulting in $61.7 \%$ 
( $\mathrm{n}=21)$, and the most common is malignant neoplasia of the rectum. This reiterates that neoplasias constitute a relevant public health problem in a global overview.

This discovery converges with the estimate of the National Cancer Institute for Brazil, in the biennium 20182019 , in which the incidence will be about 600 thousand cases of cancer, being $8.1 \%$ of colon and rectum cancer in men and $9.4 \%$ in women ${ }^{14}$, and with a survey conducted in the center-west region of Brazil ${ }^{3}$.

Cancer is responsible for $12 \%$ of all causes of death in the world. In Brazil, the increase in malignancies has been following the growth trend of life expectancy and, as a consequence, the aging of the population profile $\mathrm{e}^{14}$. It can be seen that neoplasias are the main causes of stoma formation ${ }^{13,20-21}$, followed by inflammatory diseases ${ }^{13}$.

The lack of official data by the Health Ministry about the situation of people with stomas is highlighted, in order to outline a general overview of Brazil. This may be detrimental to the construction of the epidemiological profile of these people and for adequate planning to take place and the implementation of a National Care Policy ${ }^{14}$.

The relationship between intestinal neoplasias and gaucho culture and gender is not verified in the literature; however, a high rate is observed in men with intestinal cancer in the city. And yet, because it is a border municipality, where gaucho usuals are cultivated significantly, these can be reflected in the non-prevention of this pathology, which would be done through colonoscopy and changes in eating habits, such as consumption not routine of meat. Thus, when the signs and symptoms manifest, the cancer may be at an advanced stage, requiring the preparation of the stoma.

\section{CONCLUSION}

The sociodemographic and clinical profile of people with stomas residing in Uruguaiana, RS, Brazil, revealed that the majority are elderly, with men having a higher incidence. On the other hand, neoplasias are characterized as the main etiology of the stomas.

The accomplishment of the present study was based on the importance of expanding the knowledge regarding the profile of people with registered stomas in the health service of the municipality. During the analysis of the data, it was possible to realize a reflection on the practice of care, in order to contribute to the planning of a proposal of care actions by health professionals, especially nursing professionals. Also, it is revealed that the nurse is, in most cases, responsible for registering these users, then it is necessary to reflect about the necessity to perform the correct filling of the data in the MUD, in order to obtain a more complete registration, information about this population.

The data found reveal that one of the limitations of the research was the lack of information in the data sheets of the users registered by the municipal health service in MUD. The data obtained became limiting to obtain a complete and adequate profile, because in order to plan an adequate and effective care, it is fundamental to identify if the stoma is permanent or temporary, it is not possible in this study to obtain this type of information, nor about how long the person lives with this chronic health condition. Thus, it is suggested that the health services obtain more clinical and social information from the people, not being restricted to those that make up the information systems. In this way, there will be an expansion of the characteristics, favoring a more reliable planning of the actions to the local reality.

It is hoped that the identification of the FHS to which people with stomas belong may enable the planning of future actions in partnership between educational institutions and the municipal health department, in the scope of teaching, research and extension, in order to provide care that offers guidance and support for all people who live with the stoma. It is suggested for other research that the territorialization of these people is also realized, since this makes it possible to think and organize strategies of continuing education with professionals who have this demand in their area of comprehensiveness.

\section{AUTHOR'S CONTRIBUTION}

Conceptualization, Barbosa MR; Simon BS and Tier CG; Methodology, Barbosa MR; Simon BS and Tier CG; Investigation, Barbosa MR; Simon BS and Tier CG; Writing - First version, Barbosa MR; Simon BS; Tier CG; Garcia RP; Siniak DS and Rodrigues SO; Writing Review \& Editing, Simon BS; Supervision Simon BS and Tier CG. 


\section{REFERERENCES}

1. Fernandes Jr HJ, Batocchio G, Lessa MSN. Dissecando e desmitificando o câncer. In: Bifulco VA, Fernandes Jr HJ. Câncer: uma visão multiprofissional. 2a ed. Barueri: Manole; 2014.

2. Brasil. Ministério da Saúde. Instituto Nacional de Câncer. Tipos de câncer [Internet]. 2013 [cited 13 dec. 2016]. Available at: http://www2.inca.gov.br/wps/wcm/connect/ tiposdecancer/site/home/colorretal/definicao+

3. Almeida EJ, Silva AL. Caracterização do perfil epidemiológico dos estomizados em hospitais da Secretaria de Estado de Saúde do Distrito Federal. ESTIMA, Braz J Enterestomal Ther. 2015;13(1):11-6. doi: 10.5327/z1806-3144201500010004

4. International Ostomy Association. The stoma [Internet]. 2017 [cited 2018 Jan 25]. Available from: http://www. ostomyinternational.org/ostomy-help/stoma.html

5. Moraes JT, Silva AE, Silva MDM, Guimarães RO, Ferraz GB. A percepção de cirurgiões sobre o cuidado em estomias. J HealthSci.2017;19(1):14-8. doi:10.17921/2447-8938.2017v1 9n1p14-18

6. Mauricio VC, Oliveira NVD, Lisboa MTL. O enfermeiro e sua participação no processo de reabilitação da pessoa com estoma. Esc Anna Nery. 2013;17(3):416-22. doi: 10.1590/ s1414-81452013000300003

7. Lenza NFB, Sonobe HM, Zago MMF, Buetto LS. Características socioculturais e clínicas de estomizados intestinais e de familiares em um Programa de Ostomizados. Rev Eletr Enf. 2013;15(3):755-62. doi: 10.5216/ree.v15i3.17594

8. Mendonça SN, Lameira CC, Souza NVDO, Costa CCP, Maurício VC, Silva PAS. Guidelines for nursing and implications for the quality of life of stomized people. J Nurs UFPE on line. 2014;9(suppl.1):296-304.

9. Brasil. Ministério da Saúde. Conselho Nacional de Saúde. Resolve aprovar as seguintes diretrizes e normas regulamentadoras de pesquisa envolvendo seres humanos. Resolução n. 466, 12 december 2012. Brasília, 2013.

10. Moraes JT, Assunção RS, Sá FS, Lessa ER, Corrêa LS. Perfil de pessoas estomizadas de uma região de saúde mineira. Enferm Foco. 2016;7(2):22-6. doi: 10.21675/2357707x.2016.v7.n2.788

11. Miranda SM, Luz MHBA, Sonobe HM, Andrade EMLR, Moura ECC. Caracterização sociodemográfica e clínica de pessoas com estomia em Teresina. ESTIMA, Braz J Enterestomal Ther. 2016;14(1):29-35. doi: 10.5327/z1806-3144201600010005
12. Schwalm MT, Ceretta LB, Farias BM, Bonfanti MDP, Zimmermann KCG, Perfoll R, et al. Perfil das pessoas estomizadas atendidas na Clínica Escola de Enfermagem da Universidade do Extremo Sul Catarinense - UNESC. Rev Iniciação Científica. 2013;11(1):97-105.

13. Melotti LF, Bueno IM, Silveira GV, Silva MEN, Fedosse E. Characterization of patients with ostomy treated at a public municipal and regional reference center. J Coloproctol. 2013;33(2):70-4. doi: 10.1016/j.jcol.2013.04.003

14. Brasil. Ministério da Saúde. Instituto Nacional do Câncer. Estimativa 2018 [Internet]. 2018 [cited 18 jun. 2018]. Available at: http://www.inca.gov.br/estimativa/2018/ introducao.asp

15. Tapia O, Roa JC, Manterola C, Bellolio E. Cáncer de colon y recto: descripción morfológica y clínica de 322 casos. Int J Morphol. 2010;28(2):393-8. doi: 10.4067/s071795022010000200010

16. Campos FGCM, Figueiredo MN, Monteiro M, Nahas SC, Cecconello I. Incidência de câncer colorretal em pacientes jovens. Rev Col Bras Cir. 2017;44(2):208-15. doi: 10.1590/0100-69912017002004

17. Instituto Brasileiro de Geografia e Estatística. População residente, por sexo e grupos de idade, segundo as Grandes Regiões e as Unidades da Federação - 2010 [Internet]. 2010 [cited 30 nov. 2016]. Available at: https://censo2010.ibge. gov.br/sinopse/index.php?dados $=12$

18. Brasil. Ministério do Desenvolvimento Social e Combate à Fome. Política Nacional do Idoso. Lei n. 8.842 de janeiro de 1994. Dispõe sobre a política nacional do idoso, cria o Conselho Nacional do Idoso e dá outras providências. Brasília, 2010.

19. Schimith MD, Brêtas ACP, Simon BS, Brum DJT, Alberti GF, Budó MLD, et al. Precarização e fragmentação do trabalho na estratégia saúde da família: impactos em Santa Maria (RS). Trab Educ Saúde. 2017;15(1):163-82. doi: 10.1590/19817746-sol00038

20. Ferreira EC, Barbosa MH, Sonobe HM, Barichello E. Autoestima e qualidade de vida relacionada à saúde de estomizados. Rev Bras Enferm. 2017;70(2):288-95. doi: 10.1590/0034-7167-2016-0161

21. Simon BS, Budó MLD, Schimith MD, Garcia RP, Gomes TF, Carvalho SORM. "Sempre ajudando em uma coisa ou outra": rede social da família da pessoa com estomia". Rev Eletr Enf. 2015;17(2):370-8. doi: 10.5216/ree.v17i2.29786 